disorder, he touches on most aspects of the subject. Inevitably in so brief a work his touch is light. There are chapters on the comparative and developmental aspects ; these suffer somewhat from lack of reference to the central nervous functions without which the hand itself would be inert and useless. Some varied points concerned with the general significance of the hand in human life are interestingly sketched, and the bulk of the book is devoted to discussion of specific functions such as perceiving, manipulating, plastic activity and expression. 'The book ends with a short and stimulating chapter on the magical significance of the hand. Prof. Révész is never dull, if not always satisfying. He has sketched a field worthy of a much larger work. There are a number of nice pictures. Perhaps this is why a guinea has had to be charged for scarcely forty thousand words of text.

R. C. OLdFIELd

\section{SCIENCE IN AFRICA}

Science in the Development of Africa

A Review of the Contribution of Physical and Biological Knowledge South of the Sahara. By Dr. E. B. Worthington. Pp. xix +462 . (London: Commission for Technical Co-operation in Africa South of the Sahara, and the Scientific Council for Africa South of the Sahara, 1958.) 30s. net.

T WENTY-FIVE years ago many of those concerned with developments in Africa felt that progress was impeded because there was no overall account of conditions in the various territories. One result was Lord Hailey's "African Survey", first issued in 1938 and fully revised in 1956. Dr. Worthington, also in 1938, produced his "Science in Africa", designed to supplement Lord Hailey's volume. The book now issued is a revised, rewritten and expanded successor to the earlier work.

Particularly since the end of the War in 1945, organizations have grown up to foster co-operation in the African territories. Dr. Worthington was the first secretary-general of the Scientific Council for Africa South of the Sahara, and it is on behalf of that Council and of the Commission for Technical Cooperation in Africa South of the Sahara that this book is issued.

Parallel with the great political developments which have taken place in Africa since 1938 the scope of scientific work has increased immensely, so it was clearly a monumental task that Dr. Worthington undertook when he attempted to condense all this into a book of less than four hundred pages of text. Only a man with his experience of Africa, as a research worker and as an administrator of science, could have done this. There is some account of every major, and many a minor, project in the physical and biological sciences in all the territories concerned. In all the cases in which I have any knowledge the information given, so far as it goes, is accurate and carefully checked, and what might have been a list of disconnected statements is turned into a readable story. This should be of considerable value to anyone who wants to obtain a bird's-eye view of scientific developments in the continent of Africa.

We are shown how scientific organization has increased, facilities have improved, and research has developed. At times the reader may feel that with still a comparatively small number of investigators in the field or at the bench, the organization is some. what top-heavy, and it is difficult not to sympathize with the view often expressed by actual research workers that some of the resources expended to encourage co-ordination would be better used to support original work. Also, while there have been noteworthy applications of some of the discoveries, science has still made little contribution to the increase in productivity in many of these countries which must take place if the ambitious plans of politicians are ever to be implemented. The hope of those who set up the Scientific Council was that, by international co-operation, these developments might be accelerated.

The reader who will be most disappoinced with this book is the one with a specialized knowledge of some particular problem. Dr. Worthington has had to cover such a wide field that many subjects are inevitably given sketchy and incomplete treatment. Numerous examples could be quoted. For example, though there has been a great deal of research on poultry-keeping in the tropics, here we find only ten lines of very general information in the section "Other Kinds of Stock", and two lines on Newcastle disease in the section on "Virus Infections". In another context the importance of medical training of indigenous people is referred to, but there is no mention of the ambitious medical school at Dakar, allied to the Universities of Bordeaux and Paris, or of the teaching hospital at Ibadan in Nigeria, though this must be the largest and best equipped building devoted to scientific work in the African tropics. Such deficiencies do not, however, greatly detract from the value of the book to the reader who wants only a general picture, and the bibliography may help those who wish to study particular topics more fully.

Dr. Worthington believes, as do the members of the bodies which sponsor this work, in inter-territorial co-operation. He concludes (after briefly sketching the progress of scientific work) with these words: "In the 1950's the territorial and regional barriers are breaking down through inter-African co-operation. By the 1960's we may see African science taking its full and proper place in the development of the continent". While echoing this final hope, there would seem to be some doubt as to whether the barriers are in fact breaking down. Elsewhere Dr. Worthington mentions that nationalism and tribalism, by dividing larger colonial territories into smaller self-governing States, may discourage scientific co-operation. I am inclined to think that these inevitable changes may not, in the long run, be very important. African scientific development has reached a stage where co-operation cannot be forced on it, any more than it could on the various countries of Europe. Some territories "South of the Sahara" have as much in common with countries in Asia or America as with their neighbours. Dissemination of information about scientific work in Africa, as in other areas, is now probably best through the normal international channels. Artificial regionally based organizations may well be obsolescent.

This revision, after twenty years, of Dr. Worthington's survey of 1938, is perhaps of greatest value in showing that science in Africa is growing up. As the countries of Africa take their place in the international field, specifically 'African science' is seen to be something of a myth, and we have now to deal simply with science-which is now being studied in the African continent.

KenNeth Mellanby 